\title{
Comparative study on the friction behaviour of piston/bore interface technologies
}

\author{
Josef Edtmayer $^{1}$ (D) $\cdot$ Siegfried Lösch ${ }^{2} \cdot$ Hannes Hick ${ }^{1} \cdot$ Simon Walch $^{1}$
}

Received: 1 February 2019 / Accepted: 13 May 2019 / Published online: 27 May 2019

(c) The Author(s) 2019

\begin{abstract}
Engine crank case designs for passenger car applications are based today on two main material technologies: grey cast iron and an increasing share of aluminium-based concepts. Due to the low wear resistance of aluminium, the latter concepts require a wear protective layer for the cylinder bore surface. Iron-based thermal spray coats are widely used for this purpose. The coating improves the tribological behaviour significantly, as previous studies have shown. Additionally, aluminium-based concepts offer advantages regarding engine weight and thermal management. The aim of the presented work was the discussion of these technological concepts regarding the tribological and sealing properties of the piston/bore interface. The study was carried out based on the AVL FRISC Floating Liner Engine. While the basic engine remained unchanged, the cylinder bore surface was varied. In addition to the floating liner friction measurement, the blow-by and lube oil consumption were also measured. A state-of-the-art multi-body dynamic simulation model complements the experimental study, while both simulation and measurement lead to similar conclusions.
\end{abstract}

Keywords Piston/bore interface $\cdot$ Floating liner method $\cdot$ Aluminium crank case $\cdot$ Thermal spray coating

$\begin{array}{ll}\text { Abbreviations } \\ \text { ATS } & \text { Anti-thrust side } \\ \text { BDC } & \text { Bottom dead centre } \\ \text { EHL } & \text { Elasto-hydrodynamic lubrication } \\ \text { FMEP } & \text { Friction mean effective pressure } \\ \text { IMEP } & \text { Indicated mean effective pressure } \\ \text { LOC } & \text { Lube oil consumption } \\ \text { MBD } & \text { Multi-body dynamics } \\ \text { TDC } & \text { Top dead centre } \\ \text { GDI } & \text { Gasoline direct injection } \\ \text { TS } & \text { Thrust side } \\ \text { TWA } & \text { Twin wire arc spray process } \\ \text { WOT } & \text { Wide open throttle }\end{array}$

Josef Edtmayer

josef.edtmayer@tugraz.at

1 Institute of Machine Components and Methods of Development, Inffeldgasse 21/B/II, Graz University of Technology, $8010 \mathrm{Graz}$, Austria

2 AVL List GmbH, Graz, Austria

\section{Introduction: piston/bore interface technologies}

Grey cast iron as the main material for engine crank case concepts in passenger car applications is still in competition with aluminium. The specific material properties of grey cast iron and aluminium have a major impact on engine design. In Table 1, the basic physical properties of common cast alloys for engine crank case applications are listed. Aluminium offers significantly higher heat conductivity and thermal expansion. This will result in a different piston clearance during fired engine operation. The density of an aluminium alloy is almost a third of that of grey cast iron, given a similar tensile strength. This leads to significant reductions in engine weight [1], which is the main motivation for the usage of aluminium as the favoured crank case material.

Not only do the physical properties of the presented materials differ, but the tribological performance is also different. Grey cast iron is known for its graphite content, offering self-lubrication under dry-running conditions, which is bringing benefits in the mixed lubrication regime. This appears at the piston ring/cylinder bore surface contact, especially at the dead centres.

Common aluminium alloys do not offer sufficient wear and scuffing resistance; therefore, they usually have to be 
Table 1 Physical material properties

\begin{tabular}{lllll}
\hline Alloy & Symbol & Unit & $\begin{array}{l}\text { Aluminium } \\
\text { AC-46200S }\end{array}$ & $\begin{array}{l}\text { Grey cast iron } \\
\text { EN-GJL-250 }\end{array}$ \\
\hline Density & $\rho$ & $\frac{\mathrm{t}}{\mathrm{m}^{3}}$ & $2.75^{1}$ & 7.20 \\
Therm. exp. coeff. $\left(20-200^{\circ} \mathrm{C}\right)$ & $\alpha$ & $\frac{\mu \mathrm{m}}{\mathrm{mK}}$ & 21.0 & 11.7 \\
Heat conductivity $\left(200^{\circ} \mathrm{C}\right)$ & $\lambda$ & $\frac{\mathrm{W}}{\mathrm{mK}}$ & $110-130$ & 47.5 \\
Elastic modulus & $\mathrm{E}$ & $\mathrm{GPa}$ & $75^{1}$ & $103-118$ \\
Tensile strength & $\mathrm{Rm}$ & $\mathrm{MPa}$ & 240 & $250-350$ \\
\hline
\end{tabular}

${ }^{1}[11]$

${ }^{2}$ [12]

${ }^{3}[13]$

coated. For that purpose, many different coating technologies and material combinations are known.

Nickel-silicon carbide coatings, such as Nikasil ${ }^{\circledR}$, are corrosion sensitive and the production is linked to problematic disposal of toxic nickel slurry. Additionally, casting porosities in the aluminium substrate can lead to detachments of the coating. Due to these drawbacks, this technology is not currently in wide use for passenger car applications [2].

Monolithic aluminium crank case concepts are not based on coating, but on hard silicone precipitations in hypereutectic aluminium-silicon alloys. Bad cutting properties yield a shortened tool service lifetime for all the necessary machining operations at the crank case. The required chemical etching process and the challenging assurance of a proper distribution of the silicon precipitations during the casting process result in higher costs and prevent the widespread usage of this technology. Furthermore, the wear and corrosion resistance is lower than for other technologies [3].

Thermal spray coatings are now increasingly applied for that purpose. The process of thermal spraying combines a heat source, such as a combustion flame, an electric arc or a plasma torch, with a gas flow that propels the molten coating material droplets to the substrate. Due to the partial solidification of the coating material and the distribution of the particles sprayed on the substrate, these coatings offer a specific porosity depending on the chosen process and the process parameters. This porosity is capable of retaining oil within the surface, to ensure a proper lubrication of the ring pack. The specimens used for this investigation have been steel coated ( 0.1 percent carbon content), with the aid of a twin wire arc spray process (TWA).

Independent of the chosen coating technology, a sufficient bore surface finish (honing process) is needed. Due to the oil retention properties of the porous spray coating, the surface of the liner can be made smoother than in grey cast iron concepts. Different investigations have shown a major friction reduction of thermal spray-coated aluminium cylinder bore surfaces as seen in Schommers et al. [4], An [5] and Biberger [6].

\section{Analysis methods}

The decision, whether new technologies are implemented in engine concepts, is based on various analysis methods, including tribological metrology. Widely spread strip down measurements (motored engine operation only) and tribometric rig tests have disadvantages in reproducing the thermomechanical and pressure conditions that appear at the piston group during fired engine operation, while the indicated method lacks in the ability of distinguishing influencing parameters and separating different tribological systems of the engine. Advanced analysis methods, such as floating liner friction measurements, lube oil consumption (LOC) measurements and sophisticated simulation models, allow a fundamental investigation of the main parameters for the friction reduction potential of coated aluminium cylinder bore surfaces in the context of actual engine operation conditions, as presented in this work.

The combined method approach, considering friction, blow-by, wear and LOC, complemented by a simulation model, as earlier presented in Edtmayer et al. [7], is applied for this comparative study.

\section{Floating liner measurement}

The floating liner concept allows a direct measurement of friction forces during fired engine operation and combines ideally the access of tribological quantities and application orientation, in terms of the load situation occurring in real driving conditions. The concept utilizes a cylinder liner assembly that is decoupled from the crank case to enable the installation of force sensors for capturing the friction forces, appearing within the piston/bore interaction. Due to the complexity of the system, this method is limited to single-cylinder research engines. The actual system, the presented investigations are based on, is the AVL FRISC Floating Liner Engine, previously presented 
by AVL and the authors [8, 7]. Compared to other available floating liner systems, this specific engine has some advantages. One of the most critical parts of the floating liner concept, in general, is the gasket sealing. Several different solutions are available for this. The AVL FRISC solution with a metallic sealing excels through high thermal and mechanical resistance to meet rising requirements on highly charged downsizing concepts. The utilization of three-component, piezoelectric load cells enables the investigation of piston lateral forces. Another uniqueness compared to other floating liner devices is the ability to easily adapt to different engine types, regarding crank case materials, crank train geometry and combustion process. This ability was also a main enabler for the study, presented in this paper.

For that purpose, various different cylinder liners were installed, including grey cast iron and aluminium liners, as well as liners with different surface finish and bore shape. The engine, used for this study, offers $500 \mathrm{ccm}$ displacement and is operated using a GDI combustion system, derived from a passenger car application.

\section{Simulation model}

Besides sophisticated measurement equipment for friction optimization, in engine development and also in this publication, simulation models still gain importance. The simulation of engine friction losses requires a combination of multi-body dynamics (MBD) and elasto-hydrodynamic lubrication (EHL) models as indicated in Fig. 1. For this study, the structure of the FRISC engine was implemented in the commercial MBD tool AVL Excite. In detail, the tools Excite Piston and Rings and Excite Power Unit were combined to assess the friction behaviour of the specimen investigated in the FRISC engine.

The simulation tool combination considers the main physical effects and offers good accordance with the measured friction forces from the floating liner engine, as seen in Fig. 2. The figure shows a typical friction force curve for the piston/bore interface drawn over one engine cycle: beginning with the intake stroke (down movement of the piston), compression, combustion and ending with the exhaust stroke. The simulation has one big advantage compared to the measurement: it is possible to separate the ring pack friction from the global piston share. The simulation with a validated model enables a detailed insight into the influence of the material properties. In return, the simulation benefits from the measurement with the ability of validation and extraction of friction parameters.

\section{Analysis of the friction behaviour}

The difference in the friction behaviour of the presented cylinder bore surface technologies was investigated using the previously shown floating liner method, complemented by the simulation approach. The focus of the investigation was on the differences in material properties and the surface structure of the presented cylinder bore concepts, while piston, piston rings, engine oil and crank train geometry were similar.
Fig. 1 Model definition, required for considering tribology, dynamics, and thermomechanics [10]

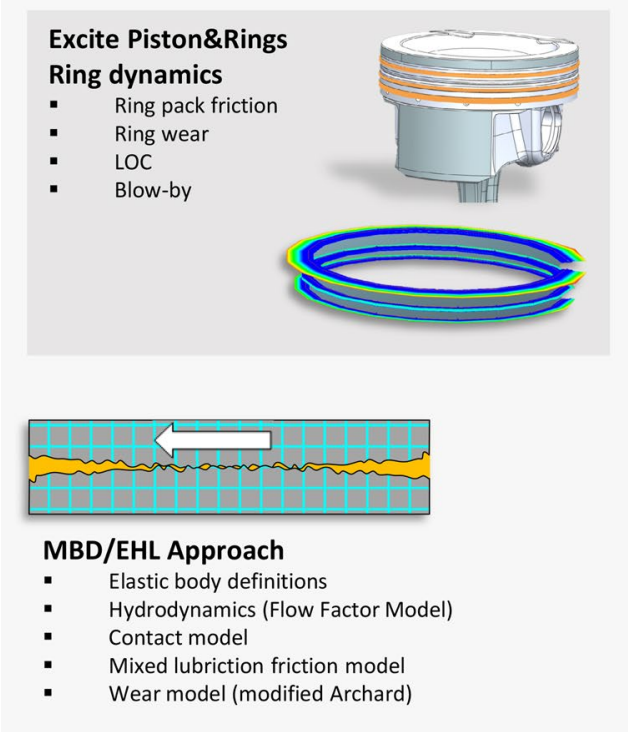


Fig. 2 Comparison of the simulated piston friction with floating liner measurements for a grey cast iron cylinder liner

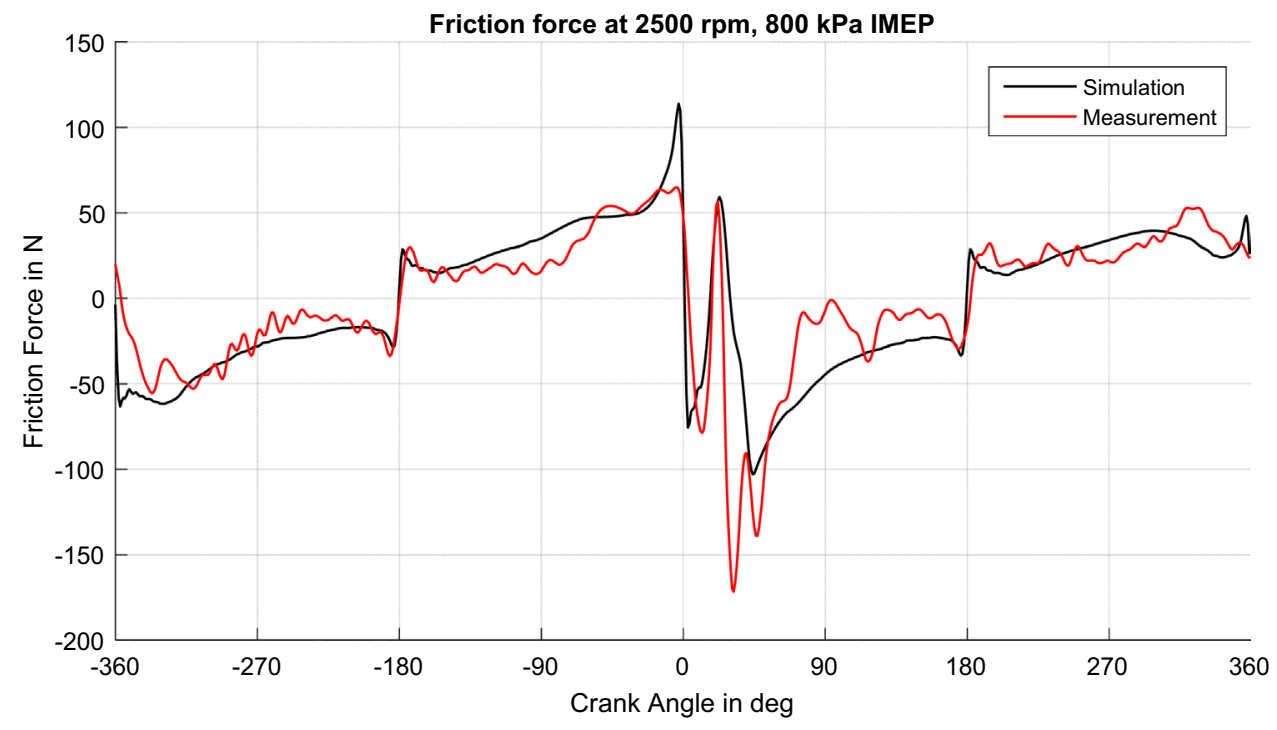

\section{Thermomechanical impact}

The different thermomechanical behaviour, especially the thermal expansion coefficient (given in Table 1) of the materials, combined with the temperature distribution at the cylinder liner due to the heat load of friction losses and combustion (Fig. 3), results in divergent piston clearance. For the investigation of the temperature distribution, the cylinder liner used in the AVL FRISC engine is equipped with twelve thermocouples. The thermocouples are placed $0.75 \mathrm{~mm}$ beneath the liner surface and are distributed over three levels (TDC, midstroke, BDC) and at TS, ATS, front and rear of the engine. The temperature distribution is strongly dependent on the engine load and also very transient. The temperatures given in the figure is representing thermally stabilized load points. However, in real driving situations, this temperature distribution will be different, depending on the driving profile, ambient temperature and engine thermal management.

The resulting shape of the liner running surface of multicylinder engines differs for various engine architectures and from cylinder to cylinder. Influencing parameters to the so-called liner distortion are the coolant circuit, the local stiffness properties and wall thicknesses of the crank case. This can be shown using the presented simulation tools, especially finite element models. For the investigation of the influence of liner distortion on the friction behaviour, the simulation offers the opportunity for keeping the tribological properties constant, while changing only the thermomechanical properties of the cylinder bore surface. Figures 4 and 5 show the impact of the thermal expansion coefficient
Fig. 3 Circumferentially averaged temperatures on the liner running surface depending on engine load at $2000 \mathrm{rpm}$

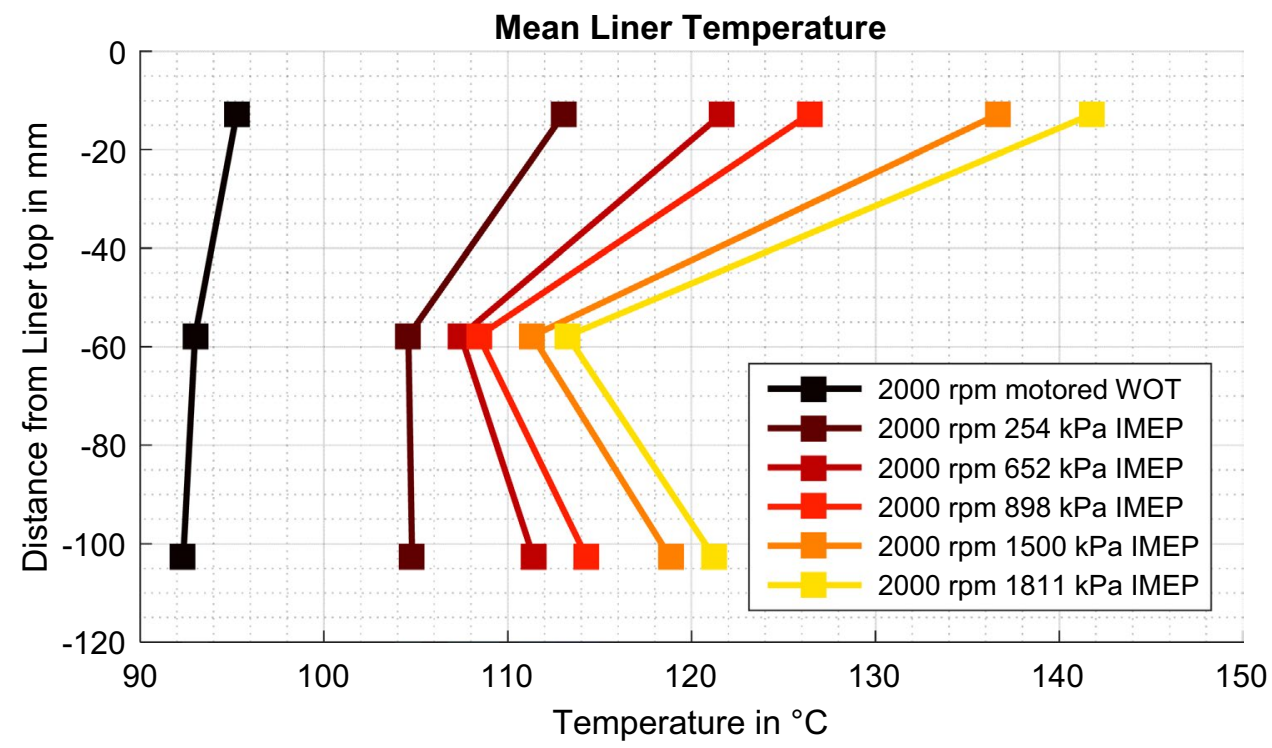


Fig. 4 Simulated piston friction for a TWA-coated aluminium liner. No friction increase due to piston overlap is identifiable
TWA coated Aluminium Liner at 2500 rpm, 800 kPa IMEP

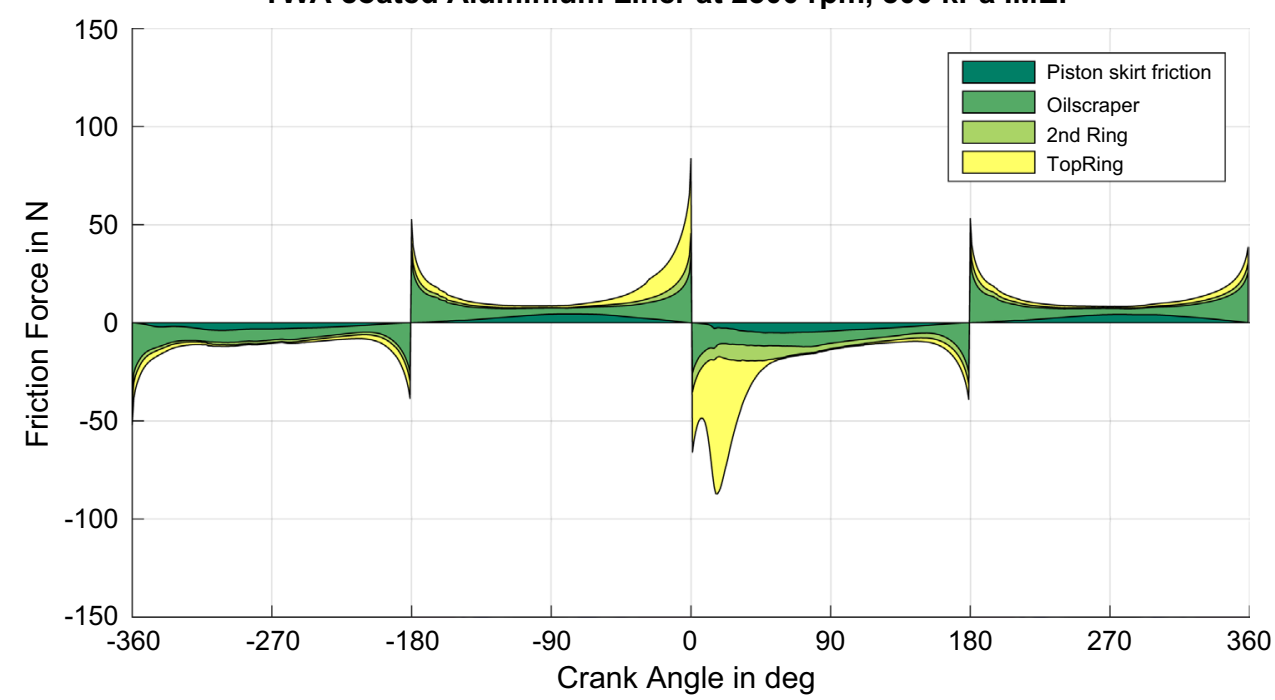

5 Simulated piston friction for a grey cast iron liner under the same tribological parameters and operating conditions as seen in Fig. 4. Grey cast iron leads to a drastic friction increase due to piston overlap
Gray Cast Iron Liner at 2500 rpm, 800 kPa IMEP

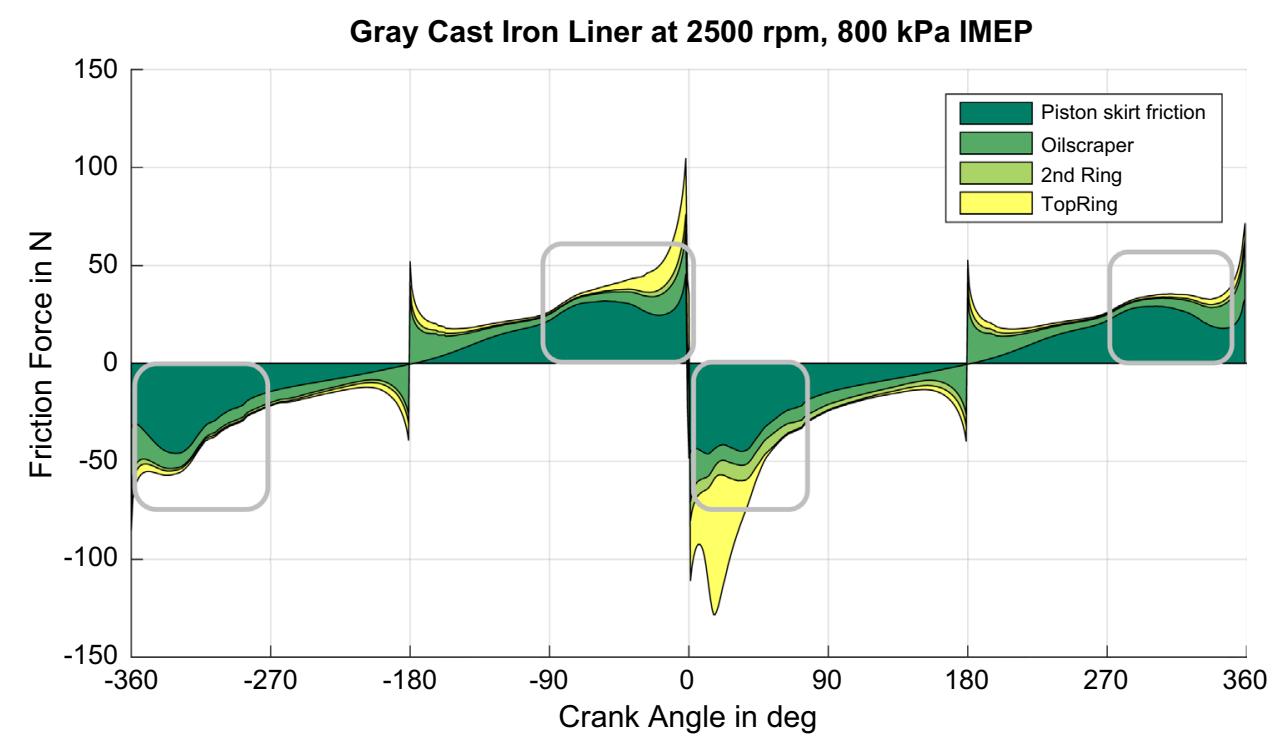

on piston clearance, resulting in a completely divergent friction performance.

While for the aluminium liner (Fig. 4) the piston offers a low friction share compared to the ring pack, a significant friction increase of the piston skirt for the grey cast iron cylinder liner can be observed in this load point (Fig. 5). The location of the friction increase at middle height of the cylinder bore surface (e.g. $0^{\circ}-90^{\circ}$ crank angle) is a characteristic caused by the temperature distribution given above. The ring friction in this simulation was not noticeably influenced by the differing thermal expansion coefficient of the cylinder bore material. However, the piston skirt friction is changed dramatically, as a result of piston overlap. The nominal piston clearance in cold conditions is 55 microns. For the aluminium cylinder bore, this is changed to almost zero in warm conditions, at the given load point $(2500 \mathrm{rpm}$, $800 \mathrm{kPa}$ IMEP). Due to the surrounding water jacket, the cylinder bore has a significantly better heat dissipation than the piston. This causes the reduced clearance, even though piston and cylinder liner have the same material properties. Considering the lower thermal expansion coefficient of grey cast iron (Table 1), the piston clearance gets negative. This means that the piston has a dimension of approximately 40 microns greater than the liner. This is especially the case in the middle range of the cylinder bore surface, as a result of the temperature distribution given in Fig. 3 (Fig. 6).

The floating liner measurement leads to the same conclusion. At lower loads (Fig. 7), the friction behaviour of both crank case technologies is quite similar. This meets the expectations, since the surface structure of both variants is 
Fig. 6 Measured friction force for a grey cast iron- and a spraycoated aluminium cylinder bore surface at low loads (1200 rpm, $650 \mathrm{kPa}$ IMEP) without piston overlap
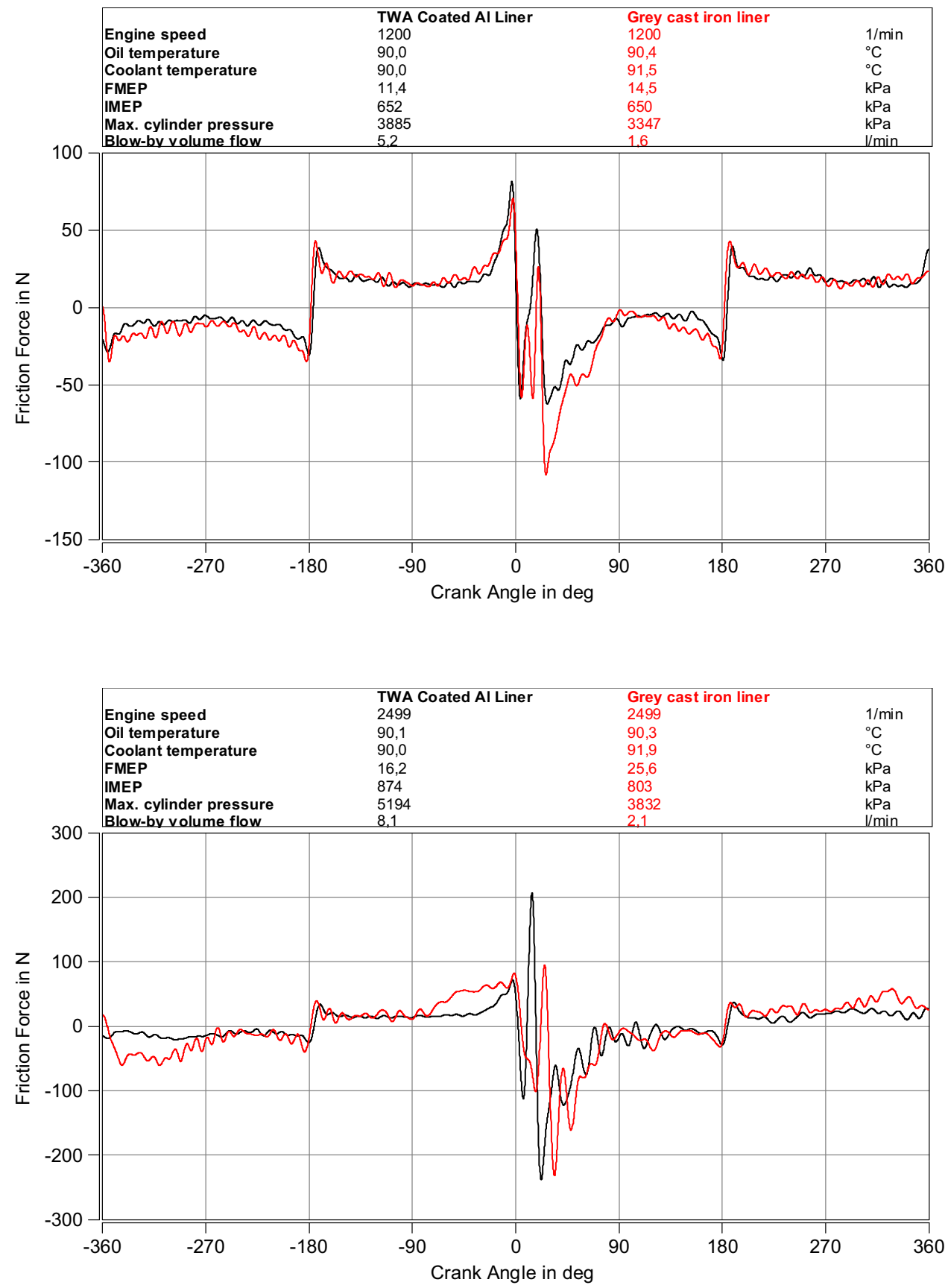

Fig. 7 Measured friction force at increased loads $(2500 \mathrm{rpm}$, $800 \mathrm{kPa}$ IMEP), indicating a severe piston overlap situation also similar, due to a grey cast iron-specific honing applied on the TWA coating of the aluminium liner. However, the friction behaviour deviates dramatically at higher loads (Fig. 7), as observed previously in the simulation results. The increased heat impact on the piston at this load point leads to higher piston temperatures and in case of a grey cast iron cylinder bore, eventually this causes an overlapping piston. Taking the friction mean effective pressure (FMEP) into consideration, representing the friction power loss and, therefore, the impact on fuel consumption, the aluminium technology leads to a reduction of about fifty percent of the friction power at the piston/bore interface, in this particular case.

\section{Contour-honed cylinder bore surface}

The friction increase due to an overlapping piston can be prevented by a specific honing profile of the liner, offering a greater cylinder diameter in regions, where the piston is prone to overlapping. This technology is already implemented in series production by some manufacturers, as 
Fig. 8 Friction force for a grey cast iron cylinder bore surface with a contoured shape and a spray-coated aluminium cylinder bore surface, showing that the profiled shape is preventing piston overlapping

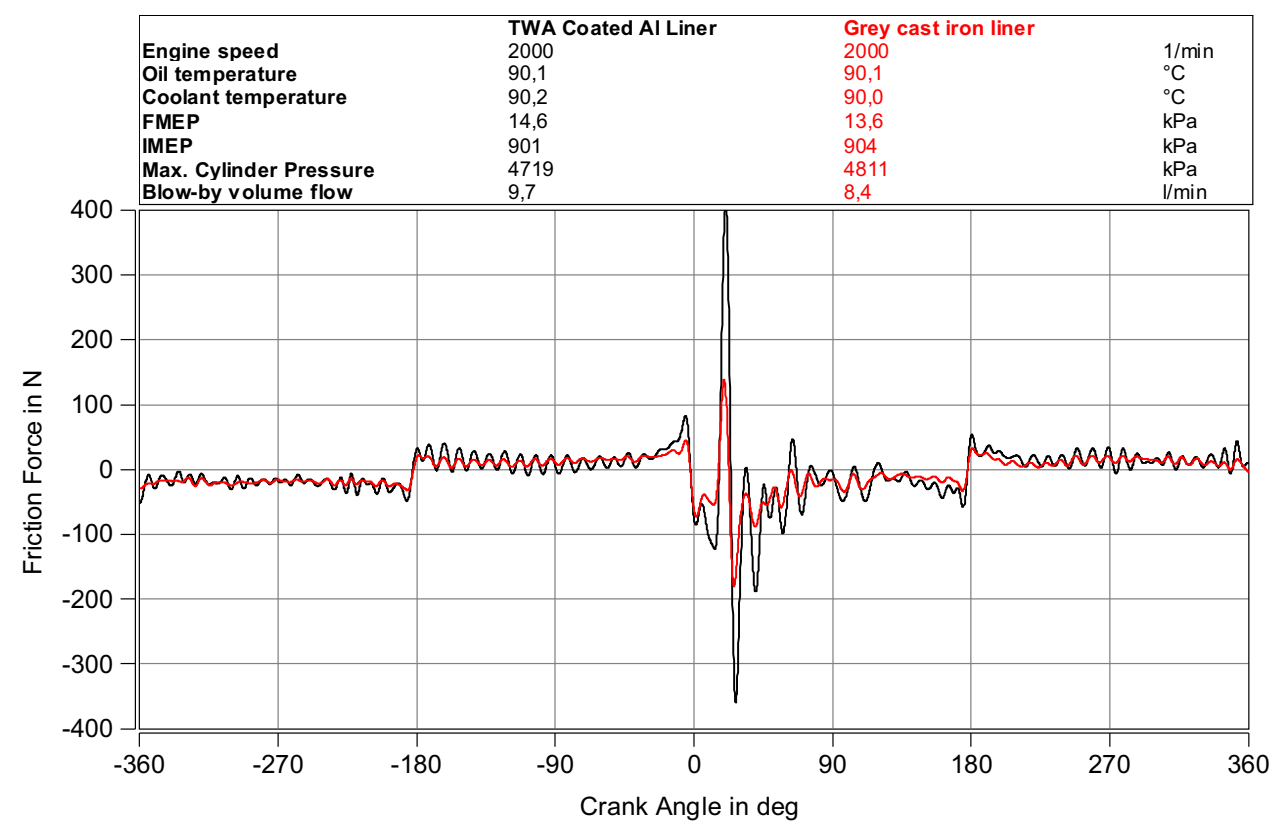

presented in Landerl et al. [9]. Figure 8 shows the comparison of two contour-honed cylinder liners with a wider diameter at the bottom. It can be seen that the friction increase due to the negative piston clearance can be avoided. Both grey cast iron and thermal spray-coated aluminium liners show a similar friction behaviour, even at higher loads and also regarding friction power. However, the blow-by volume flow is also increased for the grey cast iron liner.

The different stiffness and damping properties of aluminium and grey cast iron can also be seen in this figure.
The aluminium variant shows a significantly higher vibration content due to different elasticity and density.

\section{Surface structural impact}

For the analysis of the surface structural impact on the friction behaviour, the material was kept constant and the surface structure was defined by different surface coatings and honing process parameters.
Fig. 9 Friction comparison of a polished plateau structure with a standard grey cast iron surface structure, both on a TWAcoated aluminium liner

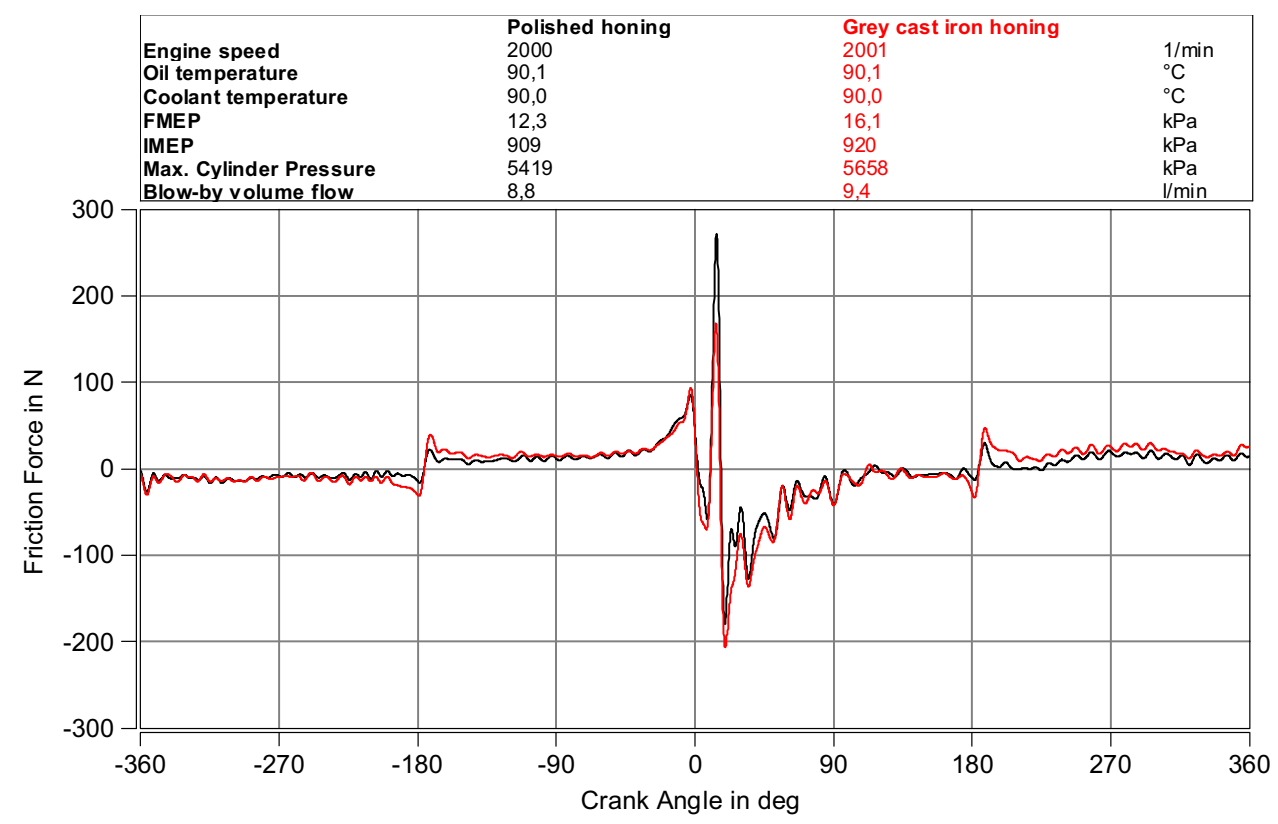


Figure 9 shows the comparison of the friction force signal of two different surface structures on coated aluminium cylinder liners: one curve showing the friction force signal of a porous TWA spray coating with a smoothed plateau surface, as it is common for this technology; the other curve showing the increased friction due to the roughness properties of a common grey cast iron technology on a TWA spray coat with reduced porosity. Due to a special polishing process, the peak roughness of the smoother variant is only a quarter of the grey cast iron variant. The oil retention volume is provided by the porosity of the coating (porosity $<5$ percent) instead of the honed structure with the typical spiral grooves. The friction reduction can be investigated especially in the charge cycles, resulting in a significant drop in friction mean effective pressure of around 25 percent. In the compression cycle and due to the peak firing pressure, a slight increase of friction is noticeable. This has tribological reasons and is subject to further investigations. The main friction reduction mechanism of TWA spray coatings in comparison to other technologies is caused by the smoother plateau surface by still providing oil within the porous coating.

\section{Oil consumption and blow-by behaviour}

The friction analysis for both simulation and floating liner friction measurement shows a clear advantage for thermal spray-coated aluminium cylinder bore technologies, due to the smoother surface and the avoidance of piston overlap.

However, the optimization of the piston/bore interface includes not only friction reduction but also wear behaviour and the sealing properties of the ring pack. The function of the ring pack is to ensure a sufficient sealing of combustion gases and lubricant. For that issue, the Lubrisense ${ }^{\circledR}$ LOCmeasurement system [14] was applied to the floating liner engine, in combination with blow-by measurement.

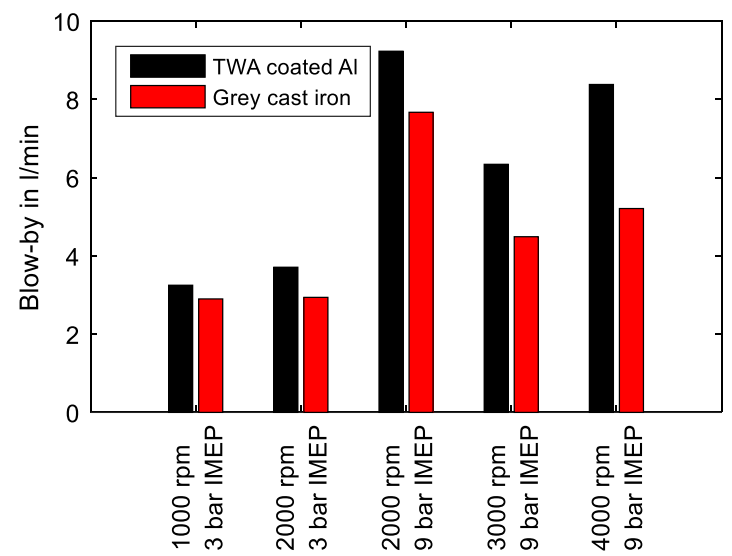

By enlarging the scope of the presented friction analysis to blow-by and LOC, the advantage of aluminium technologies decreases, as indicated in Fig. 10. The wider cylinder bore in warm conditions, due to the doubled thermal expansion coefficient, leads to an increased blow-by volume flow and LOC. This demonstrates that an isolated tribological optimization can lead to solutions that have a non-optimal overall performance of the PBI, omitting the sealing functionality of the ring pack.

\section{Summary}

Thermal spray-coated cylinder bore surfaces of aluminium crank cases are very common engine concepts and many manufacturers introduce new engine families based on this technology. The technology offers significant tribological and thermomechanical advantages in addition to the weight reduction, compared to grey cast iron crank cases. The friction reduction is mainly based on the smooth surface with oil retained in the porous surface and the different piston clearance during engine operation. The drawback of the grey cast iron technology in piston clearance can be overcome by a specific contour honing of the cylinder bore, avoiding an overlapping piston.

Higher piston clearances lead to increased blow-by and LOC in both aluminium-based concepts and grey cast iron concepts with contour-honed bore shape.

The presented work shows that engine designs, using new materials, coating technologies, cylinder bore and piston shapes as well as measures regarding the piston-ring pack, have to be checked against all these performance attributes. Future engines will need to offer low friction, blow-by and LOC while the expected service life must not be reduced. The challenge is in providing an optimal trade-off for a wide operation range, including real driving situations. Piston

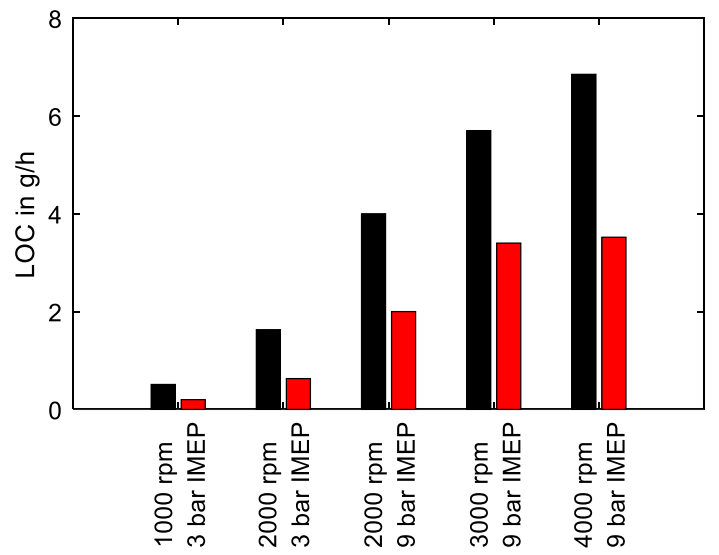

Fig. 10 Blow-by and LOC for an aluminium and a grey cast iron variant for various load points, indicating the inferior sealing properties of the aluminium cylinder bore 
overlap or increased blow-by is strongly dependent on the load point and also sensitive to transient operation since the thermal expansion of piston and cylinder liner is delayed to a change in heat impact.

The optimization and, therefore, also analysis methods for the piston/bore interface must consider all these topics. A combination of various, high-resolution analysis methods and a sophisticated modelling approach, as introduced in this work, is key to face this challenging optimization task in future.

Acknowledgements Open access funding provided by Graz University of Technology. This work was funded by the COMET Programme (Project K2 XTribology, No. 849109) of the Austrian Research Promotion Agency (FFG) and results from a cooperation of the AVL List GmbH, $\mathrm{AC}^{2} \mathrm{~T}$ research $\mathrm{GmbH}$ and the Institute for Machine Components and Methods of Development of the Graz University of Technology.

\section{Compliance with ethical standards}

Conflict of interest On behalf of all authors, the corresponding author states that there is no conflict of interest.

Open Access This article is distributed under the terms of the Creative Commons Attribution 4.0 International License (http://creativeco mmons.org/licenses/by/4.0/), which permits unrestricted use, distribution, and reproduction in any medium, provided you give appropriate credit to the original author(s) and the source, provide a link to the Creative Commons license, and indicate if changes were made.

\section{References}

1. Tanaka, T., Akasawa, T.: Machinability of hypereutectic siliconaluminum alloys. J Mater Eng Perform 08, 463-468 (1999)

2. Schäfer, A., Schilling, U., Schnaibel, S.: Überholung von Aluminium-Motorblöcken. MSI Motor Service International GmbH, Neckarsulm (2006)
3. Köhler, E., et al.: Lightweight design for cylinder blocks. Motorentechnische Zeitschrift MTZ 10, 4-12 (2009)

4. Schommers, J., et al.: Optimizing friction: the basis for safeguarding the combustion engines. 33rd International Vienna Motor Symposium, Wien (2012)

5. An, J.: Bestimmung der Schmierungs- und Reibungsverhältnisse im Kontakt Kolbenring gegen Zylinderlaufbahn von Verbrennungsmotoren in einem Modelltribometer, Dissertation, RuhrUniversität Bochum, Bochum (2014)

6. Biberger, J.: Tribologisch induzierte Oberflächenveränderungen im Reib-Verschleiß-Kontakt Kolbenring gegen Zylinderlaufbahn, Dissertation, Technische Universität Berlin, Berlin (2017)

7. Edtmayer, J., et al.: Kombinierte Tribosystemanalyse des Kontaktes Kolben-, Ringpaket/Zylinderlaufbahn auf Basis von Floating Liner Untersuchungen. Tribologie und Schmierungstechnik 65(4), 15-21 (2018)

8. Lösch, S., et al.: AVL FRISC Friction Analysis of Piston Group. ATZlive-Springer Vieweg, Esslingen (2015)

9. Landerl, C., Rülicke, M., Spanring, D., Schmuck-Soldan, S.: The next generation gasoline engine family from BMW. Motorentechnische Zeitrschrift MTZ 03, 38-45 (2018)

10. Hick, H., et al.: Emissionsreduktion und Reibungs- und Verschleißverhalten. Reibung in Antrieb und Fahrzeug 2018Springer Vieweg, Esslingen (2018)

11. Rauleder: Rauleder Aluminiumsandguss [Online]. https://www. rauleder.com/pdf/legierungen/226.pdf. Zugriff am 30 Oct 2018 (2015)

12. European Standard: DIN EN 1706:2010-06, Aluminium and aluminium alloys - Castings - Chemical composition and mechanical properties; German version. Brussels (2010)

13. European Standard: DIN EN 1561:2012-01, Founding - Grey cast irons; German version. Brussels (2012)

14. Krause, S.: Massenspektrometrisches Verfahren zur Charakterisierung der Ölverdampfung im Brennraum von Ottomotoren. Dissertation, Technische Universität Hamburg-Harburg, Hamburg (2009)

Publisher's Note Springer Nature remains neutral with regard to jurisdictional claims in published maps and institutional affiliations. 